ISSN. 2775-4324 (Online)

Journal of Physical Activity and Sports

Volume 2, Nomor 1, April 2021, 55-63

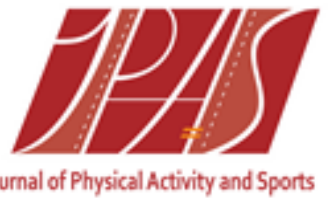

\title{
PENGARUH PENGGUNAAN MEDIA AUDIO VISUAL TERHADAP HASIL BELAJAR DRIBBLE BOLA BASKET KELAS XI SMA NEGERI 15 SEMARANG TAHUN AJARAN 2020
}

\author{
Novan Pinar Arwanda, Pandu Kresnapati, Fajar Ari Widyatmoko \\ ${ }^{1}$ Universitas PGRI Semarang. Jl. Gajah Raya No.30 B, Sambirejo, Kec. Gayamsari, Kota Semarang, Jawa \\ Tengah 50166 \\ ${ }^{2}$ Universitas PGRI Semarang. Jl. Gajah Raya No.30 B, Sambirejo, Kec. Gayamsari, Kota Semarang, Jawa \\ Tengah 50166 \\ ${ }^{3}$ Universitas PGRI Semarang. Jl. Gajah Raya No.30 B, Sambirejo, Kec. Gayamsari, Kota Semarang, Jawa \\ Tengah 50166 \\ Novanpinararwanda@gmail.com, pandukresnapati@upgris.ac.id, fajarariwidiatmoko@upgris.acid
}

\begin{abstract}
The background of the problem in this study was the lack of students' ability to perform basic basketball dribbling techniques because the students did not master the basic techniques of playing basketball. The purpose of this study was to determine how influential the audio-visual media on Dribble learning is to improve basketball Dribble learning outcomes. This study uses a Quasi Experiment Design. The sampling technique was carried out by purposive sampling. A total of 67 samples with 2 experimental classes, namely class XI MIPA 1 with a total of 30 students and class X1 MIPA 7 with a total of 35 students. Data analysis techniques used the normality test and t-test which were processed with the help of SPSS 16 software. The results of this study were obtained by analyzing the Dribble learning outcomes with the Audi visual learning model These results can be concluded that the significance value of both is more than 0.05. This means that there is no significant difference between the effect of audi visual media and Dribble learning on basic basketball technical skills
\end{abstract}

Keywords: Audio Visual, Dribble, basketball

\begin{abstract}
Abstrak
Latar belakang permasalahan dalam penelitian ini adalah kurangnya kemampuan siswa dalam melakukan teknik dasar dribble bola basket karena disebabkan siswa kurang menguasai teknik dasar dalam bermain bola basket. Tujuan penelitian ini adalah untuk mengetahui seberapa pengaruhnya media audio visual pembelajaran Dribble untuk meningkatkan hasil belajar Dribble bola basket. Penelitian ini menggunakan Quasi Exsperiment Design. Teknik pengambilan sampel dilakukan dengan purposive sampling. Jumlah 67 sampel dengan 2 kelas eksperimen yaitu kelas XI MIPA 1 dengan jumlah 30 siswa dan kelas X1 MIPA 7 dengan jumlah siswa sebanyak 35. Teknik analisis data menggunakan uji normalitas dan uji-t yang diolah dengan bantuan software SPSS 16. Hasil penelitian ini diperoleh dengan hasil analisis hasil belajar Dribble dengan model pembelajaran Audio visual. Hasil ini dapat disimpulkan bahwa nilai signifikasi keduanya adalah lebih dari 0.05. Artinya tidak terdapat perbedaan yang signifikan antara pengaruh media audio visual dan pembelajaran Dribble terhadap keterampilan teknik dasar bola basket.
\end{abstract}

Kata kunci: Audio Visual, Dribble, bola basket 
Pengaruh Penggunaan Media Audio Visual Terhadap Hasil Belajar Dribble Bola Basket Kelas Xi Sma Negeri 15 Semarang Tahun Ajaran 2020

Novan Pinar Arwanda, Pandu Kresnapati, Fajar Ari Widyatmoko

56

\section{PENDAHULUAN}

Pendidikan merupakan upaya menyiapkan peserta didik menghadapi lingkungan hidup yang mengalami perubahan dan semakin pesat di era saat ini. Pada pendidikan jasmani, peserta didik diberikan kesempatan untuk

Terlibat langsung dalam pengalaman belajar melalui aktivitas jasmani, bermain, dan berolahraga yang dilakukan secara terarah dan terencana. Tujuan dari pembelajaran pendidikan jasmania adalah merubah kemampuan peserta didik dari yang tidak menguasai materi sama sekali dapat menjadi menguasai materi meski pun tidak secara sempurna (Setiawan, 2015: 42).). Berdasarkan Permendiknas Nomor 22 tahun 2006 tentang Standar Isi menjelaskan bahwa PJOK merupakan salah satu cakupan kelompok matapelajaran kejuruan, dasar dan menengah, termasuk SMA Negeri 15 Semarang.

Proses pembelajaran penjas merupakan sebuah proses interaksi antara guru dan siswa. Pembelajaran dikatakan baik apabila seorang guru tidak hanya sebagai penyampai materi, melainkan seorang guru dituntut mampu untuk mengembangkan pemikiran siswa, agar mereka aktif dan kreatif serta antusia dalam pembelajaran tersebut .Olahraga merupakan suatu aktivitas gerak tubuh, mulai dari anggota tubuh bagian atas dan bagian bawah. Dikatakan aktivitas karena memiliki tujuan pada akhirnya,yakni kualitas hidup yang meningkat, sehingga menjadikan tubuh menjadi sehat dan bugar (Rahmani,2014).

Permainan bola basket merupakan permainan yang dimainkan oleh dua regu yang masingmasing regu terdiri dari 5 orang pemain.Tiap regu berusaha memasukkan bola ke dalam keranjang lawan dan mencegah regu lawan memasukkan bola atau membuat angka/skor .Dalam permaianan ini kerja sama tim merupakan faktor untuk meraih kemenangan. Kemenangan tersebut perlu adanya keterampilan gerak dalam menguasai teknik-teknik dasar yang baik untuk mencapai hasil yang optimal (Putu;2018).

Dribble dalam permaian bola basket bisa di artikan sebagai usaha yang dilakukan untuk membawa bola kedaerah lawan. Membawa bola dalam permainan bola basket dapat dilakukan dengan lebih dari satu langkah asal dilakukan dengan dipantulkan. Hal ini bias dilakukan dengan berjalan maupun berlari. Tangan kanan maupun kiri biasa digunakan untuk melakukan dribble dengan bergantian, akan tetapi hal yang dilarang adalah menggunakan kedua tangan untuk membawa bola. Dribble dalam permainan bola basket berguna untuk menyusup kepertahanan lawan, mengacaukan pertahanan lawan, bias juga untuk meperlambat tempo permainan, membuka peluang serangan (Kuswoyo, Riyanto; 2019).

Mendribble adalah salah satu teknik dasar bola basket yang pertama diperkenalkan kepada para siswa, karena keterampilan ini sangat penting bagi setiap pemain yang terlibat dalam 
Pengaruh Penggunaan Media Audio Visual Terhadap Hasil Belajar Dribble Bola Basket Kelas Xi Sma Negeri 15 Semarang Tahun Ajaran 2020

Novan Pinar Arwanda, Pandu Kresnapati, Fajar Ari Widyatmoko

57

pertandingan bola basket yang di mainkan oleh kedua tim masing-masing dengan 6 pemain tiap tim nya (Matheus; 2016).

Media pembelajaran harus meningkatkan motivasi siswa. Selain itu, merangsang siswa mengingat apa yang sudah dipelajari, selalu memberikan rangsangan belajar baru. Sudah selayaknya lembaga-lembaga pendidikan yang ada segera memperkenalkan dan mulai menggunakan Teknologi Informasi komunikasi sebagai basis pembelajaran yang lebih mutakhir (Darmawan,2011:4).

Selama ini banyak faktor yang menjadi hambatan dalam pembelajaran penjas khusunya bola basket. Kendala atau hambatanya adalah faktor guru, siswa, lingkungan sekolah yang kurang memadai, sarana dan prasarana yang kurang lengkap, proses pembelajaran masih monoton, alat dan media yang dipergunakan kurang bervariasi. Dari berbagai penyebab diatas hal paling mendasar yang mempengaruhi pembelajaran penjas adalah penggunaan media. Guru seharusnya tidak hanya menguasai materi akan tetapi juga harus pandai memanfaatkan media dalam menunjang pembelajaran yang akan dilakukan, karena materi akan lebih mudah tersampaikan. Oleh karena itu guru hendaknya mampu memilih media yang tepat dan sesuai dengan materi yang akan disampaikan. Yaitu menggunakan media yang tepat dalam peyampaian materi.

Menurut (Rusman, dkk. 2011; 181) Media audio visual adalah jenis media yang selain mengandung unsur suara juga mengandung unsure gambar yang bias dilihat. Media audio visual akan menjadikan penyajian bahan ajar kepada siswa semakin lengkap dan optimal. Sesuai dengan namanya, media ini kombinasi audio dan visual atau bisa disebut media pandang-dengar. Selain itu media ini dalam batas-batas tertentu dapat juga menggantikan peran dan tugas guru. Sebab, penyajian materi bisa digantikan oleh media, dan guru bisa beralih menjadi fasilitator belajar, yaitu memberikan kemudahan bagi para siswa untuk belajar (Tausikal syam,dkk;2013).

Menurut Hasil wawancara saya dengan guru mata pelajaran penjas SMA 15 Semarang bapak Iswinardi, di sekolah belum menggunakan media audio visual dan masih banyak menggunakan arahan dari guru. Berdasarkan hasil pengamatan di lapangan selama Magang 3 di SMA Negeri 15 Semarang ada beberapa siswa memiliki kemampuan yang berbeda dalam bermain bola basket terutama pada teknik dribble. Dari pengamatan peneliti dan hasil belajar dalam kegiatan pembelajaran dengan materi dribble bola basket banyak siswa yang kurang bisa melakukan teknik dribble dengan baik dan benar. Hal tersebut dikarenakan kurangnya kemampuan teknik dasar bermain bola basket yang mereka kuasai. Berdasarkan permasalahan diatas maka peneliti akan menggunakan media pembelajaran yang berbeda, maka peneliti tertarik untuk melakukan penelitian dengan judul "Pengaruh Penggunaan Media Audio Visual terhadap Hasil belajar tehnik dasar Dribble Bola Basket kelas XI SMA NEGERI 15 Semarang Tahun Ajaran 2020 
Pengaruh Penggunaan Media Audio Visual Terhadap Hasil Belajar Dribble Bola Basket Kelas Xi Sma Negeri 15 Semarang Tahun Ajaran 2020

Novan Pinar Arwanda, Pandu Kresnapati, Fajar Ari Widyatmoko

58

\section{METODE}

Penelitian ini merupakan jenis penelitian Quasi Eksperimen menggunakan pendekatan kuantitatif dengan desain pretest posttest yang memiliki hasil lebih akurat karena membandingkan keadaan sebelum dan sesudah diberi perlakuan, sehingga dapat diketahui dengan pasti perbedaan hasil perlakuan yang diberikan. Menurut Sugiyono (2017: 114) Quasi Eksperimen merupakan pengembangan dari true experimental design, yang sulit dilaksanakan. Quasi eksperimental design, digunakan karena pada kenyataannya sulit mendapatkan kelompok kontrol yang digunakan untuk penelitian.

Instrumen penelitian adalah suatu alat yang digunakan mengukur fenomena alam maupun social yang diamati. Teknik dan Instrumen yang digunakan untuk mengukur hasil belajar dalam penelitian ini adalah dengan Rubrik Penilaian Dribble Data yang diperoleh dalam penelitian eksperimen ini berupa catatan hasil pretest dan postest yang di kumpulkan melalui angket sikap untuk memenuhi aspek afektif siswa, tes dengan bulir soal tentang teknik dasar dribble bola basket untuk memenuhi aspek kognitif siswa dan melalui dribble dengan jarak 28meter untuk aspek psikomotor siswa.

\section{HASIL DAN PEMBAHASAN}

Penelitian ini bertujuan untuk mengetahui seberapa besar pengaruh model pembelajaran Media audio visual terhadap hasil dribble bola basket. Data dalam penelitian ini meliputi data pretest, dan posttest. Data hasil penelitian diolah dengan uji-t menggunakan SPSS 16 secara komputerisasi dan dianalisis untuk mengetahui hasil uji normalitas dan uji-t apakah nanti akan terdapat perbedaan yang signifikan antara pretest dan postest yang artinya apakah terdapat pengaruh penggunaan model Audio visual terhadap pembelajaran dribble bola basket Sekolah Menengah Atas 15 Semarang Bahwa penelitian ini bertujuan untuk mengetahui pengaruh hasil belajar teknik dasar bola basket dengan menggunakan model pembelajaran Drible dan model pembelajaran Media Audio Visual terhadap siswa SMA Negeri 15 Semarang kelas XI MIPA 1 dan XI MIPA 7. Subjek penelitian ini adalah siswa kelas XI MIPA 1 sebagai kelas Control menggunakan model pembelajaran Dribble dan siswa kelas XI MIPA 7 sebagai kelas eksperimen dengan model pembelajaran Media Audio Visual. Adapun urutan kegiatan yang dilakukan peneliti antara lain: (1) Pengambilan data pretest untuk mengetahui kemampuan awal siswa sebelum diberikan, pretest dilakukan dengan cara semua siswa sebagai sampel melakukan Drible dari awalan sampai ke tahap pelaksanaan teknik Drible yaitu langkah kaki kemudian lanjut tangan ujung jari memantulkan bola, dan follow trought (2) Memberikan perlakuan dengan cara kegiatan belajar mengajar seperti biasa yang menggunakan model pembelajaran Dribble pada kelas XI MIPA 1 dan model pembelajaran Media Audio Visual pada kelas XI MIPA 7 (3) Tahap akhir pengambilan data posttest dengan cara sama seperti pada waktu pengambilan data pretest, yaitu dengan melakukan teknik Dribble 
Pengaruh Penggunaan Media Audio Visual Terhadap Hasil Belajar Dribble Bola Basket Kelas Xi Sma Negeri 15 Semarang Tahun Ajaran 2020

Novan Pinar Arwanda, Pandu Kresnapati, Fajar Ari Widyatmoko

59

Berdasarkan analisis hasil data penelitian yang diperoleh pengaruh hasil belajar Drible bola basket terhadap kelompok yang diteliti. Pemberian perlakuan berupa model pembelajaran Dribble dan Media Audio Visual memberikan pengaruh terhadap hasil belajar Dribble bola basket siswa kelas XI MIPA 1 dan XI MIPA 7 SMA Negeri 15 Semarang. Dari hasil data tersebut dapat disimpulkan bahwa data mengalami peningkatan. Model pembelajaran Dribble dan Media Audio Visual bisa digunakan untuk materi bola basket teknik Dribble di mata pelajaran pendidikan jasmani.

Perlakuan Media Audio Visual lebih signifikan untuk pembelajaran bola basket teknik Dribble dibandingkan dengan perlakuan di kelas Media Audio visual. Hal ini disebabkan karena model pembelajaran Dribble siswa lebih mandiri dan siswanya pasif pada saat pembelajaran berlangsung. Bahwa dalam pembelajaran Dribble siswa di wajibkan untuk belajar bersama dengan satu kelompok dan memahami materi sampai pada cara mempraktekan teknik Dribble dengan benar. Namun terdapat kelemahan pada siswa saat peneliti menerapkan model pembelajaran Dribble, siswa masih banyak yang tidak mau belajar secara mandiri serta kurang aktif dalam mempraktekkan teknik dribble, serta di dalam pembelajaran Dribble tidak ada umpan balik antar temannya.Perlakuan di kelas Dribble cenderung susah, hal ini dikarenakan waktu pembelajaran mata pelajaran pendidikan jasmani dilaksanakan siang hari dan kurang efektif mengakibatkan siswa malas dalam mengikuti pembelajaran PJOK. Serta siswa pada kelas Dribble sedikit yang bisa memahami tentang teknik dasar bola basket dibandingkan dengan kelas Media Audio Visual. Sehingga hasil penelitiannya tidak terlalu banyak peningkatan bahkan ada beberapa yang menurun. Sedangkan di kelas experimen (Media Audio Visual) menghasilkan peningkatan antara pretest dan posttest lebih banyak dibandingkan di kelas Dribble. Hal ini disebabkan model pembelajaran Media Audio Visual lebih banyak digunakan untuk menganalisa sebuah permasalahan yang diberikan oleh peneliti. Pada saat siswa mempraktekkan teknik Dribble siswa yang lainnya menganalisa gerakkan teknik Dribble dari pelaksanaan sampai ke tahap akhir, jadi siswa dapat mengetahui dimana kesalahan dalam mempraktekkan teknik Dribble tersebut. Serta siswa mempraktekkan bagaimana cara melakukan teknik Dribble yang baik dan benar dengan tahap pelaksanaan secara runtut dan dipandu oleh guru (peneliti), serta siswa melakukan umpan balik dengan temannya. Jadi dengan pembelajaran Media Audio Visual siswa lebih paham bagaimana cara mempraktekkan teknik Dribble dengan baik.

\section{Hasil Penelitian dan Analisis Data}

Penelitian ini bertujuan untuk mengetahui seberapa besar pengaruh model pembelajaran Media audio visual terhadap hasil dribble bola basket. Data dalam penelitian ini meliputi data pretest, dan posttest. Data hasil penelitian diolah dengan uji-t menggunakan SPSS 16 secara komputerisasi dan dianalisis untuk mengetahui hasil uji normalitas dan $u j i-t$ apakah nanti akan terdapat perbedaan yang signifikan antara pretest dan postest yang artinya apakah terdapat pengaruh penggunaan 
Pengaruh Penggunaan Media Audio Visual Terhadap Hasil Belajar Dribble Bola Basket Kelas Xi Sma Negeri 15 Semarang Tahun Ajaran 2020

Novan Pinar Arwanda, Pandu Kresnapati, Fajar Ari Widyatmoko

60

model Audio visual terhadap pembelajaran dribble bola basket Sekolah Menengah Atas 15 Semarang.

Tabel 7. Hasil Pretest dan Posttet Dribble media audio Visual kelas control

\begin{tabular}{|c|c|c|c|}
\hline No & Subjek & Hasil Pretest & Hasil Posttest \\
\hline 1 & $\mathrm{X} 1$ & 9 & 10 \\
\hline 2 & $\mathrm{X} 2$ & 5 & 11 \\
\hline 3 & X3 & 7 & 8 \\
\hline 4 & $\mathrm{X} 4$ & 8 & 9 \\
\hline 5 & $\mathrm{X} 5$ & 6 & 11 \\
\hline 6 & X6 & 9 & 10 \\
\hline 7 & $\mathrm{X} 7$ & 10 & 10 \\
\hline 8 & $\mathrm{X} 8$ & 5 & 10 \\
\hline 9 & $\mathrm{X} 9$ & 8 & 9 \\
\hline 10 & $\mathrm{X} 10$ & 9 & 10 \\
\hline 11 & $\mathrm{X} 11$ & 8 & 9 \\
\hline 12 & $\mathrm{X} 12$ & 6 & 10 \\
\hline 13 & $\mathrm{X} 13$ & 8 & 9 \\
\hline 14 & $\mathrm{X} 14$ & 10 & 11 \\
\hline 15 & $\mathrm{X} 15$ & 11 & 12 \\
\hline 16 & $\mathrm{X} 16$ & 10 & 11 \\
\hline 17 & $\mathrm{X} 17$ & 5 & 11 \\
\hline 18 & $\mathrm{X} 18$ & 9 & 10 \\
\hline 19 & X19 & 6 & 10 \\
\hline 20 & $\mathrm{X} 20$ & 10 & 11 \\
\hline 21 & $\mathrm{X} 21$ & 9 & 10 \\
\hline 22 & $\mathrm{X} 22$ & 5 & 10 \\
\hline 23 & $\mathrm{X} 23$ & 9 & 10 \\
\hline 24 & $\mathrm{X} 24$ & 6 & 10 \\
\hline 25 & $\mathrm{X} 25$ & 5 & 10 \\
\hline 26 & $\mathrm{X} 26$ & 8 & 9 \\
\hline 27 & $\mathrm{X} 27$ & 8 & 9 \\
\hline 28 & $\mathrm{X} 28$ & 8 & 9 \\
\hline 29 & $\mathrm{X} 29$ & 8 & 9 \\
\hline 30 & $\mathrm{X} 30$ & 3 & 10 \\
\hline
\end{tabular}

Sumber. Data Penelitian. 2020 


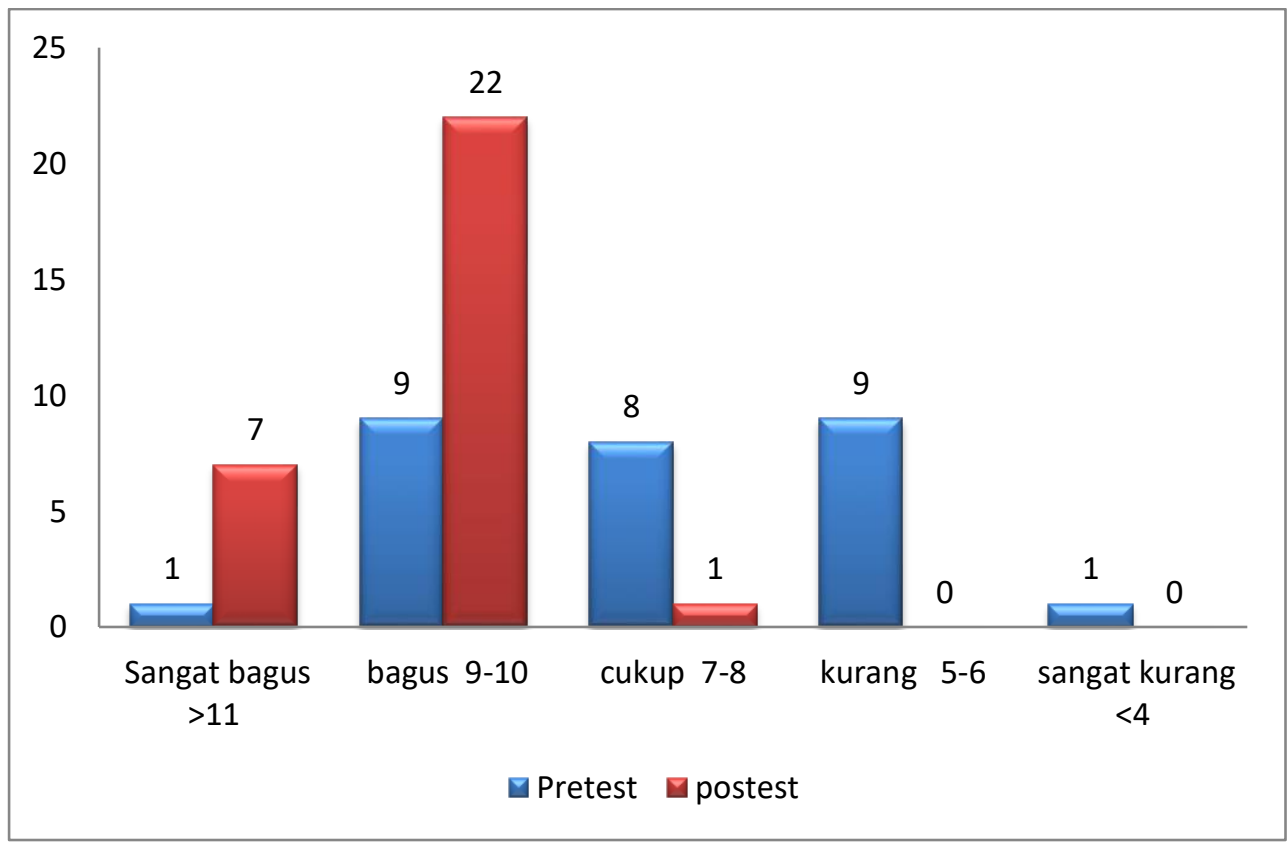

\section{Sumber: Data Penelitian (2020)}

\section{KESIMPULAN}

Berdasarkan hasil penelitian ini terdapat pengaruh yang signifikan dari penggunaan model pembelajaran Dribble dan Media Audio Visual dalam peningkatan hasil belajar Dribble siswa kelas XI di SMA Negeri 15 Semarang. Hal ini ditunjukan dari hasil penelitian sebagai berikut:

1. Hasil belajar Dribble dengan menggunakan model pembelajaran Media Audio Visual meningkat sebesar

2. Hasil belajar Dribble dengan menggunakan model pembelajaran Media Audio Visual meningkat sebesar

3. Berdasarkan presentase peningkatan hasil belajar dribble, model pembelajaran Media Audio Visual lebih efisien dibandingkan dengan model pembelajaran Dribble

Berdasarkan hasil data di atas, penggunaan model pembelajaran Dribble dan Media Audio Visual berpengaruh terhadap hasil belajar Dribble siswa kelas XI MIPA 1 dan XI MIPA 7 SMA Negeri 15 Semarang 
Pengaruh Penggunaan Media Audio Visual Terhadap Hasil Belajar Dribble Bola Basket Kelas Xi Sma Negeri 15 Semarang Tahun Ajaran 2020

Novan Pinar Arwanda, Pandu Kresnapati, Fajar Ari Widyatmoko

62

\section{DAFTAR PUSTAKA}

Ahmadi, Nuril.(2007). Permainan Bola Basket. Surakarta: Era Intermedia

Dwitama, A. (2018). "Pengaruh Metode Praktek Terhadap Belajar Dribble Dalam Pembelajaran Bola Basket (Peserta Ekstrakulikuler Siswa SMK Pasundan Subang)". Biormatika: Jurnal Ilmiah Fakultas Keguruan Dan Ilmu Pendidikan, 4(01).

Faturrohman, M. (2017). Model -Model Pembelajaran Inovatif Alternatif Desain Pembelajaran yang Menyenangkan. Ar-Ruzz Media, Jogjakarta.

Hamdayana, J. (2015). Model Dan Metode Pembelajaran Kreatif Dan Berkarakter. Bogor: Ghalia Indonesia.

Hasmyati, H. (2017, October). Penerapan Model Pembelajaran Problem Based Learning (PBL) dalam Maya Masil Belajar Pendidikan Jasmani Materi Bola Basket Siswa Kelas VIII-6 SMP Negeri 24 Makassar In Seminar Nasional Lembaga Penelitian UNM (Vol. 2, No. 1).

Jaya, U. D. S. (2016). Tingkat Keterampilan Dribble Siswa Ekstrakurikuler Bola Basket Di SMA N 1 Jepon Blora Jawa Tengah. Pend. Kepelatihan Olahraga-S1, 1(5).

Juditya, S., \& Aprila, R. N. (2018). "Pembelajaran Gerak Dasar Shooting Melalui Penerapan Model Jigsaw Berbasis Media Animasi”. TEGAR: Journal of Teaching Physical Education in Elementary School, 1(2), 53-64.

Lestari, I., dkk (2016). Penerapan Problem Based Learning (PBL) untuk meningkatkan kemampuan berpikir kritis dan sikap sosial peserta didik kelas VIII. Research Report.

Mikanda, R. (2014). Buku Super Lengkap Olahraga. Jakarta: DuniaCerdas.

Nugroho, Dian Riski,(2013)"Penerapan Model Pembelajaran Kooperatif Tipe Team Games Tournament (TGT) Terhadap Motivasi Siswa Mengikuti Pembelajaran Bola Voli Di Kelas X Sman 1 Panggul Kabupaten Trenggalek." Jurnal Pendidikan Olahraga Dan Kesehatan 1.1

Nurmala, R. S., dkk (2015). Pengaruh Strategi Problem Based Learning Dipadu Jigsaw Terhadap Kemampuan Berpikir Kritis Dan Hasil Belajar Kognitif Siswa Kelas X SMA. Jurnal Pendidikan Sains, 3(3), 130-136.

Prastyo, W. H. (2015). "Penerapan Model Kooperatif Type Jigsaw Terhadap Hasil Belajar Bola Voli Passing Atas". Jurnal Pendidikan Olahraga dan Kesehatan, 3(3).

Putra, D. S. (2014). "Penerapan Model Pembelajaran Kooperatif Tipe Jigsaw terhadap Hasil Belajar Chest Pass pada Permainan Bolabasket (Studi pada siswa Kelas VII SMP Negeri 5 Sidoarjo)". Jurnal Pendidikan Olahraga dan Kesehatan, 2(3).

Putra, D. W. A. (2017). "Pengaruh Model Pembelajaran Kooperatif Tipe TGT (Teams Games Tournament) Terhadap Ketuntasan Belajar Shooting Bola Basket (Studi Pada siswa kelas 
Pengaruh Penggunaan Media Audio Visual Terhadap Hasil Belajar Dribble Bola Basket Kelas Xi Sma Negeri

15 Semarang Tahun Ajaran 2020

Novan Pinar Arwanda, Pandu Kresnapati, Fajar Ari Widyatmoko

63

VIII SMP Negeri 1 Tulangan Sidoarjo)". Jurnal Pendidikan Olahraga dan Kesehatan, 5(1).

Setiawan, H. E. (2015). "Penerapan Model Pembelajaran Cooperative Learning Tipe Jigsaw Terhadap Hasil Belajar Dribble Sepak Bola (Studi Pada Siswa Kelas XI SMA Negeri 1 Sekaran Lamongan)". Jurnal Pendidikan Olahraga Dan Kesehatan, 3(1).

Sugiyono.(2017). Metode Penelitian Pendidikan (Pendekatan Kuantitatif, Kualitatif, dan $R \&$ D). Bandung: ALFABETA

Sulaiman Putra, D. A. V. I. (2014). Penerapan Model Pembelajaran Kooperatif Tipe Jigsaw terhadap Hasil Belajar Chest Pass pada Permainan Bolabasket (Studi pada siswa Kelas VII SMP Negeri 5 Sidoarjo). Jurnal Pendidikan Olahraga dan Kesehatan, 2(3).

Utama, I. F. (2013). "Urutan Latihan Overhead Lay Up Shot Dan Underhand Lay Up Shoot Terhadap Hasil Tembakan Lay Up Shoot Pada Siswa Ekstrakurikuler Bola Basket SMP Negeri 26 Surakarta Tahun 2012/2013". Jurnal Phederal Penjas, 1(1).

Wasito Adi Putra, dkk (2017). Pengaruh Model Pembelajaran Kooperatif Tipe Tgt (Teams Games Tournament) Terhadap Ketuntasan Belajar Shooting Bola Basket (Studi Pada Siswa Kelas VIII SMP Negeri 1 Tulangan Sidoarjo). Jurnal Pendidikan Olahraga Dan Kesehatan, 5(1).

Wicaksana, F. D. (2015). Tingkat Keterampilan Lay Up Shoot Peserta Ekstrakulikuler Bolabasket Di SMA N 1 Imogiri Bantul Yogyakarta.Skripsi. Yogyakarta: Sekolah Strata Satu UNY. Tidak diterbitkan 